\title{
Developing Electronic ESP Book for Information Systems Students
}

\author{
Zurriat Nyndia Rahmawati $^{1 *} \quad$ Urnika Mudhifatul Jannah $^{2}$ \\ 1.Information Systems Department, Universitas Islam Raden Rahmat, Jalan Raya Mojosari 02, Kepanjen- \\ Malang, Indonesia \\ 2.Informatics Department, Universitas Islam Raden Rahmat, Jalan Raya Mojosari 02, Kepanjen- Malang, \\ Indonesia
}

The research is financed by Ministry of Education and Culture, Indonesia

\section{Abstract}

English for Specific Purpose (ESP) course provides English skills and knowledge based on the students' major. The topics in ESP course are specific and developed in specially-designed learning materials. This research aimed to develop electronic book for ESP course in Information Systems department with Research and Development method by ADDIE model, that stands for Analysis, Design, Development, Implementation, and Evaluation. The e-book was designed based on the data collected in needs analysis through questionnaire, interview, and document analysis. The data showed that the currently used ESP learning materials needed to be replaced with more suitable learning materials. Based on that, the e-book was designed to comprise the recent topics in Information Systems. The e-book was divided into five chapters and the materials were presented through activities that were designed to develop students' English skills. The temporary e-book was then validated by experts and tested in the try-out with the students' representative. The e-book obtained positive feedback and was revised based on the suggestion given. The result showed that the e-book is in a good quality and feasible to be used in ESP course.

Keywords: English for Specific Purpose, Information Systems, Electronic Book

DOI: $10.7176 /$ JLLL/74-03

Publication date: December $31^{\text {st }} 2020$

\section{Introduction}

In answering global challenge, English skill has become one of the must-have skills for university graduates. The university graduates must equip their ability in their field with sufficient language mastery to present themselves better in the work field. Besides general English knowledge, during their study, the students also learn English that is specific to their major. In English for Specific Purpose (ESP), English is taught based on the needs of the target user (Hutchinson \& Waters, 1987, p. 19). ESP is designed for specific disciplines and used in particular setting; it is usually taught to the learner that has learned general English and used for professional goal (Evans \& St. John, 1998, as cited in Donesch-Jezo, 2012, p. 2). The key in teaching ESP is how to teach English as a communication tool so that it can be understood based on the field and not merely translating the topic from one language to the target language (Kenny, 2016).

(Tomlinson, 2011, p. 42) stated that in developing learning materials, there are some components that must be considered so that the materials which are developed, adopted, or adapted can meet the target setting. The components include the institution where the course is implemented, available resources of the institution, class size, type of students (their background, needs, and goal), type of the teachers (their background, needs and goal), policy of language teaching, course objective, duration of the course, type of assessment, as well as the amount of English exposure outside the classroom. Learning materials development has to support learning autonomy as well, so that the material developer needs to identify not only the learners background but also their motivation and learning habit (Debevc, et al., 2003, p. 9). Those components can also be applied and are necessary for the teachers who want to design and reach ideal ESP teaching and learning, especially where the students have specific characters and needs to be taught specific English topics.

The published books in the market may not be suitable for the students because they do not aim at specific audience with specific character and needs (Blecher, 2009, p. 7). The learning materials in English for Specific Purpose ideally must be in line with the students' level of proficiency (Cunningswort, 1995, p. 132) and the environment where the students socialize (Parkinson, 2013: 157). Particularly in engineering, the culture and values in the field are varied based on the community and countries (Parkinson, 2013, p. 157); thus, the teaching of English in engineering field cannot be directly implemented without adaptation based on the characters of the target learner.

Materials adaptation can be a solution in providing learning resources for the students. Adaptation is done by adapting the available resources to make the materials suit particular setting and make them applicable for classroom practice (Saraceni, 2011, p. 42). Materials adaptation offer practicality in terms of time and resources since the teachers can select the materials from available courses and modify it to meet the goal of the course (Duarte \& Escobar, 2008, p. 68). The teacher can add exercise to a text taken from the source, or simplify the text 
to suit the learners' proficiency level. The text from the course must be checked on its readability level because the text which is too difficult to comprehend can create frustration that leads to less engagement to the materials (Sibanda, 2014).

The theories explained previously can lead to some problems in the field, where there is limited availability of suitable materials for ESP class. Information Systems is a branch of study in engineering offered as one of the study programs in faculty of Science and Technology in Universitas Islam Raden Rahmat (UNIRA Malang) in Malang city, Indonesia. In Information Systems department, there are two English courses offered which are English I and English II. English I focuses on teaching general topics that is used in daily communication and offered in the first semester. After passing the course, the students take English II/ ESP in the second semester. The materials taught in English II is concentrated to the topics related to Information Systems. In this case, there was no specific book used in ESP course in the university. The available textbook and materials could not be directly implemented since they did not meet the characteristics of the students and context of the classroom.

Materials for English course in Information Systems department is urgently needed and can be provided by adapting the available materials to suit their needs (Brown, 2007, p. 188). Through the teaching materials that is designed based on the student needs, the students are expected to master both knowledge and language skills gradually (Hernawan, et al., 2013, p. 3). Before adapting the materials, there must be needs analysis to understand the characteristics of the students in the department, the condition of current ESP course as well as the problems and expectation to the course.

In the era of blended learning, especially with the need of online learning, there has been a trend of electronic learning materials. Electronic learning materials are served in electronic form for e-learning implementation that include not only texts and pictures but also other interactive media such as sounds and videos (Klement, et al., 2014, p. 440) that is expected to create interactive learning to the students (Debevc, 2003, p. 7). The students in this generation are also familiar with the use of electronic tools such as gadget, so that electronic books can be easily accessed and saved. Therefore, developing materials in electronic book can be a solution for the students.

\section{Research Method}

The electronic book for Information Systems students was developed by Research and Development (R\&D) method. Research and development method is utilized to design a product or procedure through a research where the output has to go through field testing, evaluation, and revision to meet the expected goal; and the R\&D for education purpose is called as educational R\&D (Gall, et al, 2003). This study used ADDIE model to develop the product. ADDIE is one of the most common R\&D models used in instructional design (Aldoobie, 2015, p. 1), that consists of several stages, namely analysis, design, development, implementation, and evaluation. The following figure shows the implementation of ADDIE in this research.
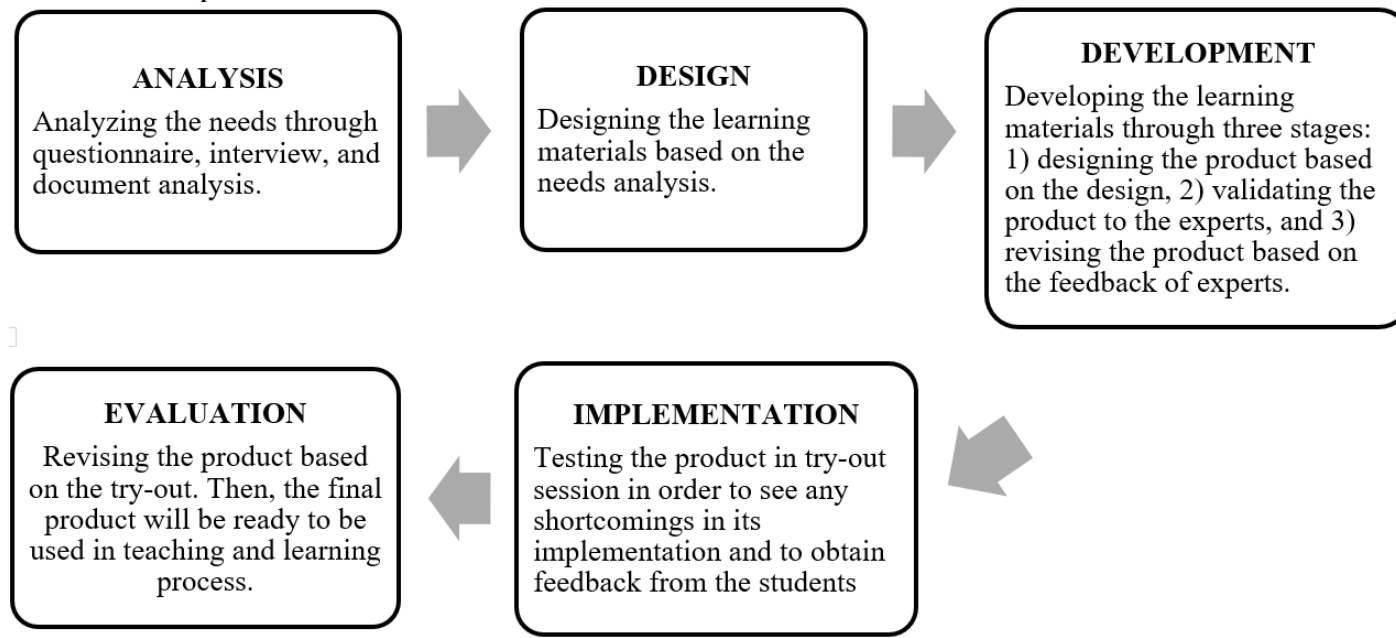

Figure 1. ADDIE Stages

In analysis stage, needs analysis data were collected by questionnaire, interview, and document analysis. The questionnaires were given to the students. It consisted of eight questions comprising close and open-ended questions. The interviews were given to the representatives of lecturers in Information Systems department. While, the document analysis was used to evaluate the current materials used in ESP course. In design stage, the materials developers developed the content of the books which included the topics, learning objective, content, as well as the assessment.

After designing and realizing the product in development stage, the materials were reviewed by two experts. The validators assessed the book based on assessment checklist that was comprised of 23 questions about the learning objectives, content, assessment, format and layout, and its implementation as e-book in e-learning. The 
answers were given in Likert scale with the scale of 1 (strongly disagree), 2 (disagree), 3 (agree), and 4 (totally agree). The total score from two validators were summed and divided by the total maximum score to find the average scores. The average scores obtained were then interpreted based on the table of score interpretation adopted from Sulistyo (2011, p. 165) as shown below.

Table 1. Score Interpretation

\begin{tabular}{|c|c|}
\hline Score & Verbal Description \\
\hline $81-100$ & Excellent \\
\hline $61-80$ & Very Good \\
\hline $41-60$ & Good \\
\hline $21-40$ & Fair \\
\hline $0-20$ & Poor \\
\hline
\end{tabular}

Based on the validation, the e-book was revised and used in in try-out session. In try-out session, the students worked on the product and gave feedback based on their experience in doing the activity in the e-book. The shortcomings found in the try-out session were used to revise the e-book again. Then the final e-book was ready to be used as the final product.

\section{Findings}

\subsection{Needs Analysis}

The needs analysis data were collected through some instruments, namely questionnaire, interview, and document analysis. The questionnaires were given to Information Systems students in UNIRA Malang through Google Form. The questionnaire included eight questions, which were: 1) the importance of English for Information Systems students; 2) the conformity of current learning materials with their major; 3) the support of the materials to learning process; 4) the difficulties found in ESP course; 5) the factors which cause difficulties in learning ESP; 6) the list of important materials to be taught in ESP course; 7) the inadequacy of current ESP course, and 8) the suggestion to develop the quality of ESP learning and teaching process.

The result of the questionnaire showed that: 1) all students agreed that English was important for them; 2) $51,9 \%$ of the students believed that ESP course delivered appropriate materials, while $48,1 \%$ of the students thought that the materials must be more appropriate; 3) 59,3\% of the students argued that the learning materials was useful to support the learning process, while the others argued that the materials must be improved in order to support the learning process; 4) three most difficult aspects in ESP course were grammar, spelling, and vocabulary; 5) there were various personal reason which contributed to their difficulties in learning ESP, 6) most of the students wanted to have adequate proportion of learning English skills in the topics related to their field, 7) the students expected that the materials can be made based on the topics in their field and neatly arranged in a form of book that is easy to be studied, and 8) the students suggested to provide more suitable materials that are implemented in effective teaching and learning process.

In the interview, there were two lecturers who were interviewed. The conclusion from the interviews were English course, especially ESP, is expected to prepare the students to have more comprehensive skills. English ability is crucial in understanding various literatures to learn other courses' learning resources which are written in English. Besides, when the students graduate from the university, they must pass English proficiency level that also become a requirement in applying for a job. English lecturer who are responsible for ESP course in Information Systems is expected to prepare the students, despite their current proficiency level, to at least be prepared with English skills to compete in the work field.

The document analysis of the current teaching materials for Information Systems students showed similar result to the result of students' questionnaire. The materials did not meet the specific topics based on the major. The materials which were developed into worksheets contained some chapters, that still contained general topics. It needed to be replaced with more updated and suitable materials for Information Systems students.

\subsection{Needs Analysis}

According to the results of need analysis, the product was designed and developed. The learning materials were compiled in an e-book consisted of five chapters, namely My Future Career, Living with Technology, Running a Procedure, Information Security, and Digital Divide. The content of the book can be seen in the following table. 
Table 2. Content of the Product

\begin{tabular}{|l|l|l|l|}
\hline \multicolumn{1}{|c|}{ Chapter } & \multicolumn{1}{c|}{ Topic } & \multicolumn{1}{c|}{ Skills } & \multicolumn{1}{c|}{ Learning Objectives } \\
\hline $\begin{array}{l}\text { I. My Future } \\
\text { Career }\end{array}$ & $\begin{array}{l}\text { Professions in } \\
\text { Information Systems } \\
\text { work field }\end{array}$ & $\begin{array}{l}\text { Listening, } \\
\text { reading and } \\
\text { speaking }\end{array}$ & $\begin{array}{l}\text { Identifying the professions in Information } \\
\text { System; and describing a dream job with its } \\
\text { job description. }\end{array}$ \\
\hline $\begin{array}{l}\text { II. Living with } \\
\text { Technology }\end{array}$ & $\begin{array}{l}\text { Positive and negative } \\
\text { impact of technology in } \\
\text { social interaction }\end{array}$ & $\begin{array}{l}\text { Reading and } \\
\text { writing }\end{array}$ & $\begin{array}{l}\text { Analyzing the positive and negative impact of } \\
\text { technology; and composing a discussion text. }\end{array}$ \\
\hline $\begin{array}{l}\text { III. Running a } \\
\text { Procedure }\end{array}$ & $\begin{array}{l}\text { Procedure of running } \\
\text { software and coding }\end{array}$ & $\begin{array}{l}\text { Reading and } \\
\text { speaking }\end{array}$ & $\begin{array}{l}\text { Identifying procedure in the text; and } \\
\text { composing and presenting procedure of doing } \\
\text { things. }\end{array}$ \\
\hline $\begin{array}{l}\text { IV. Information } \\
\text { Security }\end{array}$ & $\begin{array}{l}\text { Online data security, } \\
\text { and its cause and effect }\end{array}$ & $\begin{array}{l}\text { Reading and } \\
\text { writing }\end{array}$ & $\begin{array}{l}\text { Describing the risk in data security issues; and } \\
\text { composing cause-effect text. }\end{array}$ \\
\hline $\begin{array}{l}\text { V. Digital } \\
\text { Divide }\end{array}$ & $\begin{array}{l}\text { Society gap caused by } \\
\text { unequal access to } \\
\text { internet and technology }\end{array}$ & $\begin{array}{l}\text { Listening, } \\
\text { reading and } \\
\text { writing }\end{array}$ & $\begin{array}{l}\text { Identifying the phenomena of digital divide; } \\
\text { and composing argumentative text with } \\
\text { appropriate expression of stating facts and } \\
\text { opinion. }\end{array}$ \\
\hline
\end{tabular}

Each chapter was started with the learning objectives. The learning objectives were adopted from revised Bloom's Taxonomy, and the action verbs were selected from various stages from remembering stage to creating stage. The students were expected to be able to not only recall and explain, but also analyze and compose. The students' activity was started by connecting their background knowledge. They were asked to observe and answer some questions which led to the topics being discussed. Next, they were given list of vocabulary and pre-reading exercise before reading a text. The activity was followed by explanation and exercise on grammar and text type. Finally, in the end of each chapter, the students re we to make a product in a form of writing, video, or presentation that represented the materials they learned in the chapter.

It is necessary to bring authenticity to the classroom; thus, the cases and questions in the background knowledge section were taken from the real and recent issue to help them connected what they learned in the classroom and how to implement it in the real world. The texts were adapted from various open resources in Information Systems field, and some of them were simplified to be matched with appropriate readability level of the students. The learning materials were also completed with various pictures taken from open sources website. Besides, as the benefit of developing electronic book, there were links to the videos used in learning activities.

\subsection{Expert Validation and Try-out}

The e-book was validated by two experts in English language teaching from who have numerous experiences in the field. They assessed the e-book based on the checklist given by the materials developers. The result of the expert validation is shown in the table below.

Table 3. Expert Validation Score

\begin{tabular}{|l|c|c|}
\hline \multicolumn{1}{|c|}{ Chapter } & Average Score & Interpretation \\
\hline I. My Future Career & 79,8 & Very Good \\
\hline II. Living with Technology & 83,1 & Excellent \\
\hline III. Running a Procedure & 83,1 & Excellent \\
\hline IV. Information Security & 82,6 & Excellent \\
\hline V. Digital Divide & 82,6 & Excellent \\
\hline
\end{tabular}

Based on the validation result, it could be interpreted that the product obtained positive feedback. The e-book was feasible to be implemented. The validators also gave some notes and suggestions to improve the product. The materials developers had consultation for the improvement of the e-book, and it was then revised again.

The revision of e-book was tested in the try-out session. The try-out session invited the representative of the students in Information Systems. The students worked on the e-book which was given through the e-learning platform of UNIRA Malang, so that the students could experience the real use of e-book for blended learning or e-learning. The material developers observed the try-out session and the students were given questionnaire to write their feedback.

From the try-out, it was concluded that the book was ready to be used in the real classroom setting yet the teacher could not fully dependent to the e-book because the key to successful learning was the interaction between students and the teacher. The teacher must support the students to be active in the classroom and provided them with various activities. The students' opinions that were collected showed that the new e-book has been suitable with their field in Information Systems. The e-book was also interesting and provided new insight to them. Some of the materials also had higher difficulty level than the previous materials used in ESP, so that the teacher was 
expected to assist them more during the course. Overall, the e-book was well-accepted by the students. Based on the observation and students' feedbacks, the e-book obtained minor revision. After the second revision, the final product of the e-book was ready to be used in ESP course.

\section{Conclusion}

It was necessary to develop book for ESP course to meet the demand of specific classroom setting, in which in this study was designed for Information Systems students in UNIRA Malang. The needs analysis showed that the teacher-made learning materials as well as books in the market were not adequate and suitable to equip the students with English skills based on their major in Information Systems. Based on the needs analysis, the e-book was developed. The book contains five chapters namely: My Future Career, Living with Technology, Running a Procedure, Information Security, and Digital Divide. The e-book was validated by experts and obtained satisfying score which showed that the e-book was feasible to be used in the classroom. The try-out session with the students also indicated that the e-book was suitable for Information Systems students. The final product in the form of ebook is ready to be used in ESP course.

\section{References}

Aldoobie, N. (2015) 'ADDIE Model', American International Journal of Contemporary Research, 5(6),68-72 [online]. Available at: http://www.aijcrnet.com/journals/Vol_5_No_6_December_2015/10.pdf (Accessed: 15 January 2020)

Blecher, D. (ed.) (2009). English for Specific Purposes in Theory and Practice. Michigan: University of Michigan Press.

Cunningswort, A. (1995) Choosing Your Coursebook (Handbooks for the English Classroom). London: Macmillan Education.

Debevc, M., et al. (2003) E-learning Material Planning and Preparation [online]. Available at: www.researchgate.net/publication/267719367 E-learning material planning and preparation (Accessed: 27 August 2020)

Donesch-Jezo, E. (2012) 'English for Specific Purposes: What does it mean and why is it different from teaching General English?', CONFLUENCE [online]. Available at: https://www.researchgate.net/publication/308914571_English_for_Specific_Purposes_What_does_it_mean and why is it different from teaching_General_English (Accessed: 8 May 2020)

Duarte, S.A. \& Escobar, L.A. (2008) 'Using Adapted Materials and Its Impact on University Students’ Motivation', PROFILE Issues in Teachers' Professional Development Journal, 9,63-87 [online]. Available at: http://www.scielo.org.co/scielo.php?script=sci_arttext\&pid=S1657-07902008000100005 (Accessed: 8 May 2020)

Hernawan, A.H., et al. (2010). Pengembangan Bahan Ajar [online]. Available at: http://file.upi.edu/Direktori/FIP/JUR. KURIKULUM DAN TEK. PENDIDIKAN/194601291981012-

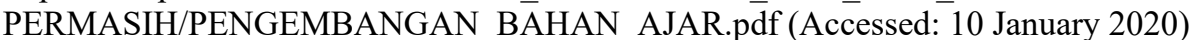

Hutchinson, T. and Waters, A. (1987) English for Specific Purposes: A learning-centered approach. Cambridge: Cambridge University Press

Kenny, N. (2016) 'Is There a Specific Method for Teaching ESP?', Journal of Teaching English for Specific and Academic Purposes, 4(2), pp. 253-260.

Klement, M., et al. (2014) 'Elements of Electronic Teaching Materials with Respect to Student's Cognitive Learning Styles', Procedia: Social and Behavioral Sciences, 112,437-446 [online]. Available at: https://www.sciencedirect.com/science/article/pii/S1877042814012038 (Accessed: 20 October 2020)

Parkinson, J. (2013). 'English for Science and Technology' in Paltridge, B. \& Starfield, S. (eds.), The Handbook of English for Specific Purpose. New Jersey: John Wiley\& Sons Inc., pp. 155-157.

Saraceni, C. (2011). 'Adapting Courses: A Personal View' in Tomlinson, B. (ed.), Material Development in Language Teaching. Cambridge: Cambridge University Press, pp. 49-62.

Sibanda, L. (2014) 'The Readability of Two Grade 4 Natural Sciences Textbooks for South African Schools', South African Journal of Childhood Education, 4(2),e1-e22 [online]. Available at: https://sajce.co.za/index.php/sajce/article/view/209/57 (Accessed: 1 October 2020)

Sulistyo, G. H. (2011) Reading for Meaning: Theories, Teaching Strategies and Assessment. Malang: Pustaka Kaiswaran.

Tomlinson, B (ed.). (2011). Material Development in Language Teaching. Cambridge: Cambridge University Press. 